\title{
Chimaeras Obtained by the Nuclear Transplantation Technique in the Mouse
}

\author{
Kosho Nakamura* and Yukio Tsunoda \\ National Institute of Animal Industry, Tsukuba Norindanchi P.O. Box 5, \\ Ibaraki 305, and *on leave of abscence from Safety Evaluation Lab, \\ of Kaken Pharmaceutical Co., Ltd., 14 Shinomiya, Minami Kawara-cho, \\ Yamashina-ku, Kyoto 607
}

(Accepted for publication May 6, 1987)

\begin{abstract}
Summary. The present study was undertaken to produce chimaeras by using nuclear transplantation technique in the mouse. The nuclear transplantation was performed between BALB $/ \mathrm{c} \times \mathrm{BALB} / \mathrm{c}$ embryo (GPI-1, a/a and albino) and $\mathrm{F} 1(\mathrm{C} 57 \mathrm{BL} / 6 \mathrm{~J} \times \mathrm{CBA})$ $\times$ CBA embryo (GPI-1, b/b and non-albino) at 2-cell stage.

The results obtained are as follows.

1. The proportion of F1 embryos which received BALB nucleus and developed to blastocyst stage was significantly higher than that of BALB embryos receiving F1 nucleus $(62 \%$ vs $42 \%)$.

2. Chimaeras were obtained after transfer of F1 embryos receiving BALB nucleus to the uterus of recipient CD-1 females $(38 \%)$. On the other hand, BALB embryos receiving Fl nucleus did not produce chimaeric mice.

3. The results of the analysis of chimaeric state showed that BALB/F1 ratio of coat color patterns almost coincided with GPI-1 a/b ratio in the red blood cells but not in the germ cell line. KEY WORDS; CHIMAERA, NUCLEAR TRANSPLANTATION, MOUSE EMBRYO.
\end{abstract}

Jpn J Anim Reprod 33, 82-87, 1987

\section{核移植技術を用いたキメラマウスの作出}

中村 公章* ・ 角田 幸生

農林水産省畜産試験場, *科研製薬（株）安全性研究所

キメラ動物とは複合動物という意味であり， 2 個以上 の遉伝的に異なる細胞集団から構成された動物を示すの に使われている（McLaren, 1976)。キメラマウスは, これまで2つの異なった方法によって作出されている。 すなわち, Tarkowski (1961) および Mintz (1962a) に よって開発された胚の集合による方法と Gardner(1968) によって考察された顕微注入による方法である。前者の 集合法は, 透明带を除去した 2 個以上の肧を集合させて 1 つの巨大な胚とする方法であり, 必要とする装置が少 ないこと，操作が容易であること等の利点がある。しか しながら, 用いる胚のステージが限定される欠点があ
り， 2 細胞 (Mintz, 1962b; Mulnard, 1971) および 4 細胞期（Hillman et al., 1972）あるいは初期胚盤胞 (Stern and Wilson, 1972) 同士の集合も試みられてい るがキメラ作出率が低いことから，粘着力の強い 8 細胞 前後のステージの肧を用いる必要がある。後者の注入法 は, 胚盤胞の腔内に他の細胞を顕微注入する方法であ り，特殊な装置および高度な技術を必要とする欠点があ るが, 発生過程の異なる胚やテラトーマ細胞 (Dewey et al., 1977) 由来のキメラを作出できる利点がある。 また，透明帯を除去した胚の移植によって産仔が得られ ないウサギのような動物種にも適用できる（Moustafa, 
1974）利点がある。

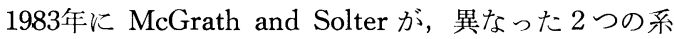
統のマウス前核期受精卵間で前核の置換を行うことによ って産仔の作出に成功して以来, 核移植技術は哺乳動物 の初期発生過程における核と細胞質の相互作用や遺伝子 発現機構の解明の手段として有効に利用され始めてい る。本実験は，マウス 2 細胞期胚の片側割球の核を置換 することによって，キメラマウスが作出できるか否かを 検討することを目的に実施した。

\section{材料と方法}

供試動物 アルビノである $\mathrm{BALB} / \mathrm{c}$ 系および有色 の F1（C57BL/6J×CBA）成熟雌を用いた。Glucosephosphate isomerose-1(GPI-1)のサブタイプは, BALB /c 系で a/a，F1 では b/b である。それぞれ PMSG と hCG を投与して過劋排卵誘起後, BALB/c あるいは CBA (GPI-1 b/b) 系の雄と交配し， hCG 注射後45〜 47 時間目に卵管を灌流して採取した 2 細胞期胚を用いた。 胚の回収は M2 液（Fulton and Whittingham, 1978）を 用い，採取した胚は流動パラフィン（英国 $\mathrm{BDH}$ 社製， No. 29436）下の M16液（Whittingham，1971）内に移 して，核移植を行うまで $5 \% \mathrm{CO}_{2}, 95 \%$ 空気の炭酸ガ ス培養器内に静置した。

核移植 既報（角田ら, 1985; Tsunoda et al., 1986) の方法を用いて，2つの系統の 2 細胞期胚片側割球核の 交換移植を行った。まず，核移植に先立ってマイクロピ ペットの挿入を容易にするため供試するすべての肧の透 明带の 1 部 $(10 \sim 20 \%)$ をガラス針で切断し，小孔をあ けた。ついで，BALB $\times$ BALB（以下 BALB 系と称す る） 2 細胞期胚の片側割球より，マイクロピペットを用 いて少量の細胞質を含む核(カリオプラスト)を吸引除去 し，ピペットの外にはき出した。次に，F1×CBA（以 下 F1 と称する）より採取した 2 細胞期胚の片側割球か ら同様にカリオプラストをピペット内に吸引した。F1 由来のカリオプラストを同量の不活化センダイウィルス (HVJ，2700 HAU $/ \mathrm{ml})$ とともに，あらかじめ片側割球 より核を除去してある BALB 系 2 細胞期胚の 細胞質に 注入し，注入後 2 時間目に注入核と細胞質の融合を観察 した。またこの逆の組み合わせで核移植を実施した。 すなわちこのような 2 細胞期胚の片側割球核の交換移植 によって，一方の割球で BALB 系の細胞質+BALB 系 の核，他方の割球で BALB 系の細胞質 $+\mathrm{F} 1$ の核の組 久合わせの 2 細胞期胚と, 一方の割球が F 1 の細胞質 + F1の核，他方の割球が F1の細胞質 + BALB 系の核の
2 種類の 2 細胞期胚が新しく作出できたことになる。融 合が確認できた胚は M16 液内で 3 日間体外培養して肧 盤胞期への発生率を調べ, 胚盤胞期に発育した肧は偽妊 娠 3 日目（胠栓のみられた日を1日目とする）のマウス の子宮内に移植した。受卵マウス（CD-1系）は，2 度に わたって不妊であることを確認した精管結紮雄（CD-1 系）と交配したものを用いた。なお，対照実験として無 処置の BALB 系および F1 2 細胞期胚を48～72時間培 養して桑実胚および胚盤胞への発生率を調べ，ついで得 られた胚盤胞を受卵マウスに移植して妊娠率ならびに産 仔生産率を調べた。

キメラの判定 得られた産仔がキメラであるか否か は, 産仔の眼色, 毛色ならびに血中 GPI-1 型により判 定した。CPI-1 の測定は, 尾静脈より採取した血液か ら血球を分離後, 蒸留水で溶血させたのち Eicher and Washburn (1978) および Mikami and Onishi (1985) の方法により, Titan III Iso-vis セルローズアセテート 膜（ヘレナ研）を用いて電気泳動法により行い，クリニ スキャンデンシトメーター (ヘレナ研)を用いて GPI-1 ${ }^{\mathrm{a}}$ と GPI-1 ${ }^{\mathrm{b}}$ の比率を測定した（Mikami and Onishi, 1985)。得られたキメラマウスの 1 部については, 生殖 能力ならびに生殖細胞におけるキメラ状態を調べる目的 で, 雄では 2 匹の雌と, 雌では 1 回それぞれ CD-1系ア ルビノマウスと交配して産仔の毛色を調べた。

\section{結果}

Table 1 に, 無処置の BALB 系および F1×CBA 2 細胞期胚の体外培養ならびに発育肧を移植後の産仔生産 成績を示した。表に示すように，本実験で用いた実験条 件下では，BALB 系胚の桑実胚 $(63 \%)$ および胚盤胞 $(47 \%)$ への発生率は, F1×CBA 胚 (98\% および 97\%) に比べて有意（P<0.001）に低いことが明らかとなっ た。また，体外培養によって得られた肧盤胞の移植結果 でも，BALB 系に拈ける産仔生産率 (41\%) は，F1X CBA $(71 \%)$ に比べて有意 $(\mathrm{P}<0.05)$ に低いことが知 られた。

Table 2 に核移植胚の培養成績を示した。BALB 系の 核を注入した F 1 泼では，操作臕 188 個中 116 個 (62\%) が胚盤胞に，58個 $(31 \%)$ が片側割球のみ胚盤胞に発生 した。逆に F1の核を注入した BALB 系では，操作臕 153 個中65個 (42\%) が胚盤胞に，58個（38\%）が片側 割球の夕胚盤胞に発生し，残りの30個 $(20 \%)$ は桑実胚 期以前で発生を停止した。胚盤胞への発生率は両者間で 有意差 $(\mathrm{P}<0.001)$ がみられた。なお，片側割球のみが 
Table 1. In vitro and in vivo development of 2-cell mouse embryos from BALB/c strain and F1

\begin{tabular}{lcccccc}
\hline Strain & $\begin{array}{c}\text { No. of } \\
\text { embryos } \\
\text { cultured }\end{array}$ & \begin{tabular}{c} 
No. of embryos developed to \\
\cline { 3 - 5 }
\end{tabular} & $\begin{array}{c}\text { morulae } 1) \\
(\%)\end{array}$ & $\begin{array}{c}\text { blastocysts }{ }^{2)} \\
(\%)\end{array}$ & $\begin{array}{c}\text { No. pregnant/ } \\
\text { No. of recipients } \\
(\%)\end{array}$ & $\begin{array}{c}\text { No. of young/ } \\
\text { No. of blastocysts } \\
\text { transferred } \\
(\%)\end{array}$ \\
\hline BALB $\times$ BALB & 175 & $110(63) *$ & $82(47) *$ & $13 / 13(100)$ & $21 / 51(41) * *$ \\
F1 $\times$ CBA & 106 & $104(98)$ & $103(97)$ & $11 / 11(100)$ & $36 / 51(71)$ \\
\hline
\end{tabular}

1) examined $48 \mathrm{hrs}$ after culture

2) examined $72 \mathrm{hrs}$ after culture

$* \mathbf{P}<0.001 \quad * * \mathbf{P}<0.05$

Table 2. In vitro development of micromanipulated 2-cell embryos following allogeneic exchange of single nucleus

\begin{tabular}{|c|c|c|c|c|c|}
\hline \multirow{2}{*}{$\begin{array}{l}\text { Donor } \\
\text { nucleus }\end{array}$} & \multirow{2}{*}{$\begin{array}{l}\text { Recipient } \\
\text { embryo }\end{array}$} & \multirow{2}{*}{$\begin{array}{l}\text { No. of embryos } \\
\text { cultured }\end{array}$} & \multicolumn{3}{|c|}{ No. of embryos developed to $(\%)$ : } \\
\hline & & & Blastocyst & $\begin{array}{c}\text { Incomplete } \\
\text { Blastocyst }\end{array}$ & Others \\
\hline BALB $\times$ BALB & $\mathrm{F} 1 \times \mathrm{CBA}$ & 188 & $\begin{array}{l}116 \\
(62)\end{array}$ & $\begin{array}{l}58 \\
(31)\end{array}$ & $\begin{array}{c}14 \\
(7)\end{array}$ \\
\hline $\mathrm{F} 1 \times \mathrm{CBA}$ & $\mathrm{BALB} \times \mathrm{BALB}$ & 153 & $\begin{array}{l}65^{* * *} \\
(42)\end{array}$ & $\begin{array}{c}58 \\
(38)\end{array}$ & $\begin{array}{l}30 * * \\
(20)\end{array}$ \\
\hline
\end{tabular}

** $\mathbf{P}<0.001$

Table 3. In vivo development of blastocysts developed from reconstituted 2-cell embryos after transfer to the uterus of the recipient females

\begin{tabular}{|c|c|c|c|c|c|c|c|c|}
\hline \multirow{3}{*}{ Donor nucleus } & \multirow{3}{*}{$\begin{array}{l}\text { Recipient } \\
\text { embryo }\end{array}$} & \multirow{3}{*}{$\begin{array}{l}\text { No. pregnant/ } \\
\text { No. of } \\
\text { recipients } \\
(\%)\end{array}$} & \multirow{3}{*}{$\begin{array}{c}\text { No. of young/ } \\
\text { No. of } \\
\text { blastocysts } \\
\text { transferred } \\
(\%)\end{array}$} & \multicolumn{5}{|c|}{ No. of young at weaning } \\
\hline & & & & \multirow{2}{*}{ Sex } & \multirow{2}{*}{$\begin{array}{l}\text { No. of } \\
\text { young }\end{array}$} & \multicolumn{3}{|c|}{ Coat color (\%) } \\
\hline & & & & & & Colored & Albino & Chimaera \\
\hline \multirow{3}{*}{$\mathrm{BALB} \times \mathrm{BALB}$} & \multirow{3}{*}{$\mathrm{F} 1 \times \mathrm{CBA}$} & \multirow{3}{*}{$12 / 14(86)$} & \multirow{3}{*}{$42 / 110(38)$} & Male & 18 & 7 & 0 & 11 \\
\hline & & & & Female & 21 & 14 & 3 & 4 \\
\hline & & & & Total & 39 & $\begin{array}{c}21 \\
(54)\end{array}$ & $\begin{array}{c}3 \\
(8)\end{array}$ & $\begin{array}{c}15 \\
(38)\end{array}$ \\
\hline \multirow{3}{*}{$\mathrm{F} 1 \times \mathrm{CBA}$} & \multirow{3}{*}{$\mathrm{BALB} \times \mathrm{BALB}$} & \multirow{3}{*}{$3 / 9(33)$} & \multirow{3}{*}{$10 / 51(20) *$} & Male & 5 & 5 & 0 & 0 \\
\hline & & & & Female & 5 & 5 & () & 0 \\
\hline & & & & Total & 10 & $\begin{array}{c}10 \\
(100)\end{array}$ & 0 & 0 \\
\hline
\end{tabular}

$* \mathrm{P}<0.05$

胚艋胞へ発生した胚についてはどちらの核由来のもので あるか判別できなかった。

Table 3 に培養により発生した胚盤胞の移植成績およ び得られた産仔のキメラ状態を示した。BALB 系の核 を注入した F 1 胚より発生した 110 個の胚盤胞を14匹の 受卵雌に移植したところ，12匹 $(86 \%)$ が妊娠し42匹 $(38 \%)$ の産仔が得られた。F1の核を注入した BALB 系胚由来の胚盤胞51個の移植成績では，妊娠率 (33\%, 3/9）が低く, また産仔生産率（20\%，10/51）も逆の組
み合わせに比べて有意（ $\mathrm{P}<0.05 ）$ に低かった。キメラ 個体は, BALB 系の核を注入した F1胚の移植によっ てのみ得られた。すなわち, 離乳時まで生存した39匹の 産仔の毛色による判定の結果, キメラは雄18匹中11匹 (Fig. 1)，雌21匹中 4 匹（Fig. 2）の計15匹（38\%）で みられ，F1用の毛色のみを示す個体は雄 7 匹, 雌14 匹の計21匹 $(54 \%)$, BALB 系由来の毛色のみを示す個 体は雌にのみ 3 匹 $(8 \%)$ みられた。これに対して，F1 核を注入した BALB 系胚の移植で得られた10匹の産仔 


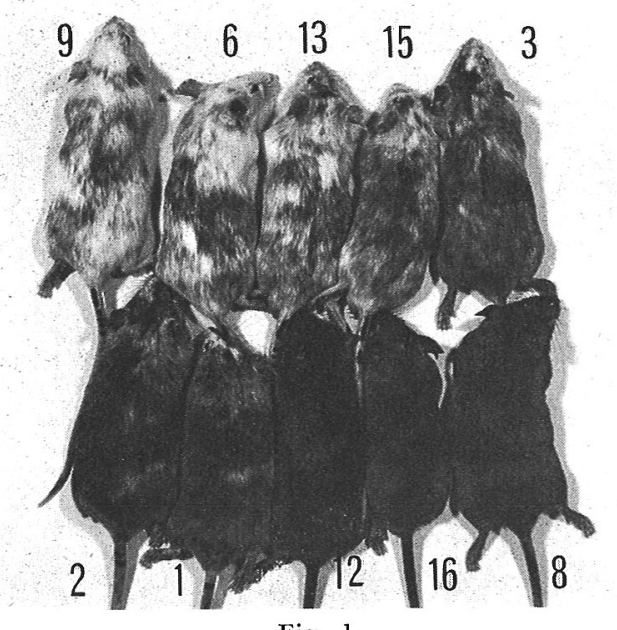

Fig. 1.

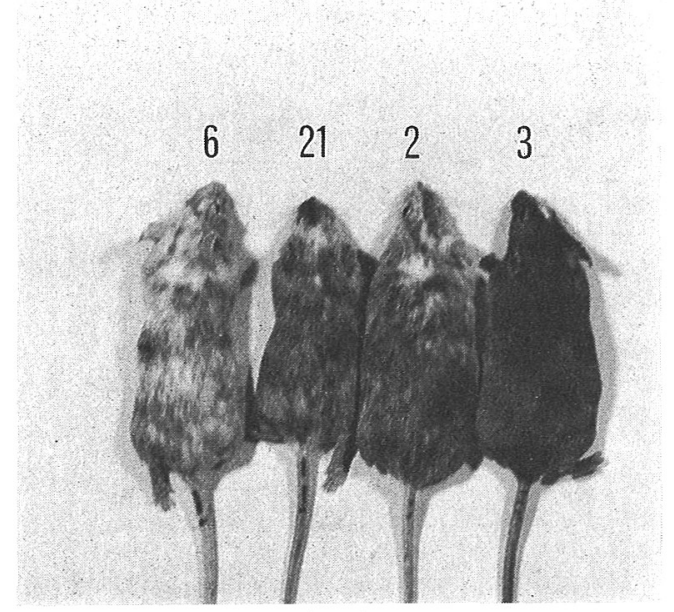

Fig. 2

(1)

Male (Fig. 1) and female (Fig. 2) chimaeras obtained by nuclear transplantation. Each figure in plates, except No. 15 in Fig. 1 and No. 21 in Fig. 2 denotes the mouse number in Table 3.

はすべて F1由来の毛色を示しフコル゙ノおよびキメラ 個体は得られなかった。

Table 4 と, 得られたキメラ個体雄 8 匹, 雌 3 匹の血 中 GPI-1 型の比率㘧よび生殖能力の検定結果を示した。 GPI-1 型の分析では， b 型のみを示す個体から， a 型 の比率が高い個体までのばらつきがみられたが，全体と してb 型の比率，すなわち $\mathrm{F} 1 \times \mathrm{CBA}$ 由来の遺伝子の発 現割合が高かった。これらキメラ個体の GPI-1 型の比 率は，それぞれの個体に批りる毛色の此率（Figs. 1 and 2）とほぼ一致した傾向を示した。

生殖能力の愉定試験では，雄 8 匹のらち 1 匹（No.6） が 2 匹の雌と 2 週間同居させたが交尾せずに不妊におお り, また雌 3 匹のうち 1 匹 (No. 6) が交尾後妊娠が成立 しなかった。妊娠した 9 匹のキメラのらち，有色とアル ビノの産仔が同時に得られた個体は 4 匹であり, これら の個体では生殖細胞がキメラ状態になっていることが判 明した。残り，5匹のキィラ個体のうち 3 匹では産仔の 毛色が有色であり, 逆に 2 匹の個体の産仔はすべてアル ビノであった。これらのキメラ個体の生殖細胞は，いず れか一方の系統の遺伝子から構成されていることが明ら

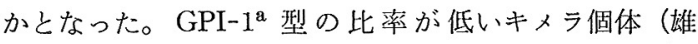
No. 2 の $13.2 \%$, No. 3 の $21.2 \%$ 扎よび雌 No. 2 の 35\%) でる，a型である BALB 系由来の毛色（アルビ 1) を示す産仔の比率が高く $(19 / 22,31 / 31,5 / 6)$, GPI-1の比率と生殖細胞におけるキィラ状態は一致しな かった。 
Table 4. Individual data of chimaeric mouse on GPI-1 type in red blood cells and reproductive ability

\begin{tabular}{|c|c|c|c|c|c|c|c|c|c|}
\hline \multirow{3}{*}{ Sex } & \multirow{3}{*}{$\begin{array}{l}\text { Animal } \\
\text { No. }\end{array}$} & \multirow{2}{*}{\multicolumn{2}{|c|}{$\begin{array}{l}\text { R. B. C. } \\
\text { GPI-1 ratio }(\%)\end{array}$}} & \multicolumn{6}{|c|}{ Fertility } \\
\hline & & & & \multirow{2}{*}{$\begin{array}{l}\text { No. pregnant/ } \\
\text { No. of mated }\end{array}$} & \multirow{2}{*}{$\begin{array}{l}\text { No. of } \\
\text { young }\end{array}$} & \multicolumn{2}{|c|}{ Sex of young } & \multicolumn{2}{|c|}{ Coat color } \\
\hline & & $\mathrm{b}$ & a & & & Male & Female & Colored & Albino \\
\hline \multirow[t]{8}{*}{ Male } & 1 & 74.0 & 26.0 & $1 / 2$ & 15 & 8 & 7 & 15 & 0 \\
\hline & 2 & 86.8 & 13.2 & $2 / 2$ & 22 & 13 & 9 & 3 & 19 \\
\hline & 3 & 78.8 & 21.2 & $2 / 2$ & 31 & 19 & 12 & 0 & 31 \\
\hline & 6 & 45.5 & 54.5 & $0 / 2$ & - & - & - & - & - \\
\hline & 8 & 100 & 0 & $2 / 2$ & 30 & 11 & 19 & 27 & 3 \\
\hline & 9 & 41.0 & 59.0 & $2 / 2$ & 24 & 8 & 16 & 0 & 24 \\
\hline & 12 & 100 & 0 & $2 / 2$ & 26 & 12 & 14 & 26 & 0 \\
\hline & 13 & 74.8 & 25.2 & $2 / 2$ & 27 & 11 & 16 & 23 & 4 \\
\hline \multirow[t]{3}{*}{ Female } & 2 & 65.0 & 35.0 & Pregnant & 6 & 3 & 3 & 1 & 5 \\
\hline & 3 & 100 & 0 & Pregnant & 10 & 7 & 3 & 10 & 0 \\
\hline & 6 & 57.5 & 42.5 & No. pregnant & - & - & - & - & - \\
\hline
\end{tabular}

1980)。

本実験で用いた培養条件下では，無処置の F1×CBA 2 細胞期胚の胚盤胞への発生率および胚盤胞を移植後の 産仔生産率は, 無処置の BALB 系 2 細胞期胚に比べて 高い（Table 1)。核移植技術を用いて作出したキメラ胀 では, 細胞質が BALB 系由来である場合, F1×CBA 由 来である場合に比べて胚盤胞への発生率が低く（Table 2)，また移植後の産仔生産率も低い(Table 3)ことから , 人為操作に対する BALB 系胚の感受性の強さは核よ りもむしろ細胞質に依存していると考えられる。

核と細胞質の組み合わせの違いによってキメラ臕の発 生率およびキメラ個体の作出率が異なるといら点を除け ば，核移植によって得られたキメラマウスの所見は集合 法あるいは注入法によって得られた個体と大差がみられ ない。すなわち，得られたキメラマウス15匹のうち11匹 が雄 $(73 \%)$ であり, キメラマウスの性は雄に偏ること， キメラ個体の毛色分布と GPI 型の比率は相関すること, GPI 型の比率と生殖細胞のキメラ状態とは一致しない こと（McLaren, 1976）などが明らかとなった。

\section{謝辞}

センダイウィルスを供与いただいた大阪大学細胞工学 センター内田驍教授に深謝する。また，赤血球 GPI-1 型 の分析にあたり御指導いただいた当場育種部三上仁志博 士ならびに大西彰研究員，実験をお手伝いいただいた小 野寺政一氏 (現, バイオ科学研究所), 御校閲いただい た花田章繁殖部長ならびに家畜改良事業団家畜改良技術 センター杉江佶博士に深謝する。

\section{References}

Dewey MJ, Matrin DW, Martin GR,Jr., Mintz B (1977) Mosaic mice with teratocarcinoma-derived mutant cells deficient in hypoxanthine phosphoribosyltransferase. Proc Natl Acad Sci USA 74: 5564-5568.

Eicher EM, Wachburn LL (1978) Assignment of genes to regions of mouse chromosomes. Proc Natl Acad Sci USA 75: 946-950.

Fulton BP, Whittingham DG (1978) Activation of mammalian oocytes by intracellular injection of calcium. Nature (Lond) 273: 149-151.

Gardner RL (1968) Mouse chimaeras obtained by the injection of cells into the blastocyst. Nature (Lond) 220: 596-597.

Hillman N, Sherman MI, Graham C (1972) The effect of spatial arrangements on cell determination during mouse development. J Embryol exp Morph 28: 263-278.

Kelly SJ, Mulnard JG, Graham CF (1978) Cell division and cell allocation in early mouse development. $J$ Embryol exp Morph 48: 37-51.

McGrath J, Solter D (1983) Nuclear transplantation in the mouse embryo by micromanipulation and cell fusion. Science 220: 1300-1302.

McLaren A (1976) Mammalian Chimaeras, Cambridge University Press, Cambridge.

Mikami H, Onishi A (1985) 'Heterosis' in litter size of chimaeric mice. Genet Res Cam 46: 85-94.

Mintz B (1962 a) Formation of genotypically mosaic mouse embryos. Amer Zool 2: 432.

Mintz B (1962 b) Experimental recombination of cells in the developing mouse egg: normal and lethal mutant genotypes. Amer Zool 2: 541-542. 
Moustafa LA (1974) Chimaeric rabbits from embryonic cell transplantation. Proc Soc exp Biol Med 147: 485-488.

Mulnard JG (1971) Manipulation of cleaving mammalian embryos with special reference to a timelapse cinematographic analysis of centrifuged and fused mouse eggs. Adv Biosci 6: 255-274.

Rossant K, Vijh KM (1980) Ability of outside cells from preimplantation mouse embryos to from inner cell mass derivatives. Dev Biol 76: 475-482.

Stern MS, Wilson IB (1972) Experimental studies on the organization of the preimplantation mouse embryo. I. Fusion of asynchronously cleaving eggs.
$J$ Embryol exp Morph 28: 247-254.

Tarkowski AK (1961) Mouse chimaeras developed from fused eggs. Nature (Lond) 190: 857-860.

Tsunoda Y, Yasui T, Tokunaga T, Uchida T, Sugie T (1985) Pronuclear transplantation in the mouse. Jpn J Anim Reprod 31: 130-134 (in Japanese).

Tsunoda Y, Yasui T, Nakamura K, Uchida T, Sugie T (1986) Effect of cutting the zona pellucida on the pronuclear transplantation in the mouse. $J$ Exp Zool 240: 119-125.

Whittingham DG (1971) Culture of mouse ova. J Reprod Fert Suppl 14: 7-21.

\footnotetext{
要 約

核移植技術を用いて， BALB $\times$ BALB および F1×CBA の 2 細胞胚期間で片側割球核の交換移植 を行いキメラマウスの作出を試みた。得られた結果の概要は次の通りである。

1. BALB 系の核を注入した F1 胚の胚盤胞への発生率 $(62 \%)$ は，F1 の核を注入した BALB 系胚の発生率 $(42 \%)$ に比べて有意に高かった。

2. 培養胚の移植により，BALB 系の核を注入した F1 胚で, 産仔の $33 \%$ (15/39) に体毛キメラ が得られた。しかしながら，逆の組み合わせではキメラ個体は得られなかった。

3. GPI-1 型の比率と体毛のキメラ状態は一致したが, 生殖細胞では異なっていた。
} 